\title{
Induced pluripotent stem cells in Alzheimer's disease: applications for disease modeling and cell-replacement therapy
}

\author{
Juan Yang ${ }^{2 \dagger}$, Song $\mathrm{Li}^{1 \dagger}, \mathrm{Xi}^{-B i a o} \mathrm{He}^{4}$, Cheng Cheng ${ }^{1}$ and Weidong Le $\mathrm{e}^{1,2,3^{*}}$
}

\begin{abstract}
Alzheimer's disease (AD) is the most common cause of dementia in those over the age of 65 . While a numerous of disease-causing genes and risk factors have been identified, the exact etiological mechanisms of AD are not yet completely understood, due to the inability to test theoretical hypotheses on non-postmortem and patient-specific research systems. The use of recently developed and optimized induced pluripotent stem cells (iPSCs) technology may provide a promising platform to create reliable models, not only for better understanding the etiopathological process of AD, but also for efficient anti-AD drugs screening. More importantly, human-sourced iPSCs may also provide a beneficial tool for cell-replacement therapy against AD. Although considerable progress has been achieved, a number of key challenges still require to be addressed in IPSCs research, including the identification of robust disease phenotypes in AD modeling and the clinical availabilities of iPSCs-based cell-replacement therapy in human. In this review, we highlight recent progresses of iPSCs research and discuss the translational challenges of AD patients-derived iPSCs in disease modeling and cell-replacement therapy.
\end{abstract}

Keywords: Alzheimer's disease, Cell-replacement therapy, Disease modeling, Drugs screening, Induced pluripotent stem cells

\section{Background}

Alzheimer's disease (AD) is the most common form of dementia that begins with short-term memory deficits and culminates in total loss of cognition and executive functions. The formations of amyloid- $\beta$ (A $\beta$ ) plaques and intracellular neurofibrillary tangles (NFTs), two important pathological hallmarks of AD, have been linked to the synapse loss, neuronal degeneration and subsequent dramatic brain atrophy of $\mathrm{AD}$ patients $[1,2]$. Although these clinical features and pathological profiles of $\mathrm{AD}$ have been well documented and various animal models containing AD-related genetic backgrounds have been developed, the etiological mechanisms for $\mathrm{AD}$ are still far from being

\footnotetext{
*Correspondence: wdle@sibs.ac.cn

${ }^{\dagger}$ Equal contributors

${ }^{1}$ Center for Translational Research on Neurological Diseases, the First Affiliated Hospital, Dalian Medical University, 116021 Dalian, China

${ }^{2}$ Key Laboratory of Stem Cell Biology, Institute of Health Sciences, Shanghai Institutes for Biological Sciences, Chinese Academy of Sciences/Shanghai Jiao Tong University School of Medicine, 200031 Shanghai, China

Full list of author information is available at the end of the article
}

fully understood and effective therapeutic strategies for $\mathrm{AD}$ are still urgently needed.

Dozens of drugs and therapeutic strategies attempting to slow or halt neuronal loss and cognitive deficiency of $\mathrm{AD}$ are being investigated around the world [3]. However, only five pharmacological agents have been approved for clinical AD treatment by the Food and Drug Administration, including cholinesterase inhibitors tacrine, donepezil, galantamine, rivastigmine and $\mathrm{N}$ methyl-D-aspartate (NMDA) receptor antagonist memantine [4]. Unfortunately, all these currently available pharmacological therapeutics only relieve symptoms without affecting the major pathological characteristics of $\mathrm{AD}$. Moreover, the effectiveness of these agents varies from person to person as evidenced by a moderate efficiency in no more than $20 \%$ of patients and tolerance, noncompliance and side-effects in more than $60 \%$ of treated patients [5].

Several theoretical hypotheses have been raised for elucidating the pathological mechanisms of $\mathrm{AD}$, including amyloid-cascade hypothesis [6], tau hypothesis [7], 
mitochondrial cascade hypothesis [8], oxidative stress hypothesis [9] and neuroinflammation hypothesis [10]. Among them, amyloid-cascade hypothesis is widely accepted as the centerpiece of $A D$ pathology, in which $A \beta$ is recognized as the initiating factor in AD. Previous studies have reported that $A \beta$ plaque deposition, an early critical event of $\mathrm{AD}$, triggers the downstream features of $\mathrm{AD}$ including tangles formation, oxidative stress, neuroinflammation and neuronal loss. Several new candidates targeting $A \beta$ have been tested in clinical trials in past years. Unfortunately, all of these therapeutic candidates failed to improve the cognitive and functional ability of $\mathrm{AD}$ patients, yet caused serious side-effects $[11,12]$. Therefore, a better understanding of the upstream mechanisms of $\mathrm{AD}$ pathology is urgently required for the discovery of novel disease-modifying therapeutic strategies.

Till now, at least 3 causal genes and 22 risk genes have been identified to be involved in the pathogenesis of $\mathrm{AD}$, including amyloid precursor protein (APP), presenilin-1/ 2 (PSEN1/2) [5, 13], apolipoprotein E (APOE) [14], ABCA7, BIN1, CASS4, CD33, CD2AP, CELF1, CLU, CR1, DSG2, EPHA1, FERMT2, HLA-DRB5-DBR1, INPP5D, MS4A, MEF2C, NME8, PICALM, PTK2B, SORL1, SLC24H4-RIN3, and ZCWPW1 [15]. However, genetic factors could only partially explain the risk of $\mathrm{AD}$. The notion widely accepted to date is that the onset of $\mathrm{AD}$ is most likely the consequence of complicated interactions of multiple genetic and non-genetic factors (Fig. 1) [16]. Several non-genetic risk factors have been proposed, including aging, cerebro-cardiovascular diseases, metabolic disorders, traumatic brain injury, sleep disorders, chronic hypoxia and environmental toxins [3, 17-23]. However, the mechanisms underlying them still remain largely unknown, due to the lack of nonpostmortem and $\mathrm{AD}$ patient-specific research models.

The identification of $\mathrm{AD}$ causal genes resulted in the generation of more than 150 transgenic $\mathrm{AD}$ mouse models, by over-expressing one or more mutated genes such as human APP, PSEN1/2, or Tau [24]. These transgenic models have greatly advanced the understanding of $\mathrm{AD}$ pathogenesis and promoted the findings of novel therapeutic targets and strategies for $\mathrm{AD}$ treatment. However, none of these transgenic models can reflect all pathogenic and clinical features of AD. Different combinations and extents of gene mutations led to a great variety of $A D$ phenotypes $[25,26]$. Although $A \beta$ plaques and cognitive impairment were observed in almost all animal models, NFTs could only be generated by lines over-expressing human tau protein. Cholinergic neuronal loss can be observed in several lines, but massive neuronal loss in brain is rarely observed in these animal models. Based on these, in the current stage transgenic animal models cannot fully recapitulate the progress of human AD. In addition, the transgenic animals carrying autosomal dominant familial AD (FAD) genes may have limitations in modeling sporadic AD (SAD) [27, 28]. Therefore, more representative models are needed for facilitating the fundamental $\mathrm{AD}$ research and exploring more efficient therapeutic strategies for AD treatment.

The recently developed and optimized induced pluripotent stem cells (iPSCs) technology may provide an appealing access to overcome these challenges in $\mathrm{AD}$ research. iPSCs can be generated from somatic cells by using several key transcription factors for pluripotency. iPSCs are in general identical to embryonic stem cells (ESCs) with the ability to self-renew unlimitedly and differentiate into all cell types [29-31]. Additionally, human iPSCs derived from patients'own somatic cells may serve as a sufficient cell source for clinical transplantation therapy (also termed as cell-replacement therapy), which can efficiently prevent immunologic rejection and the ethical issues raised by the use of ESCs [32, 33]. More importantly, human iPSCs derived from either FAD or SAD patients' somatic cells contain a patient-specific pathogenic background, therefore, can provide a promising avenue for $\mathrm{AD}$ modeling, which bridges the gap between animal models and clinical testing. This strategy is extremely useful for the mechanism understanding of AD pathogenesis, clinical identifying of therapeutic targets and drug screening of the novel therapeutic candidates against $\mathrm{AD}$ (Fig. 2). In this review, we update the recent progress of iPSCs research, and discuss its potential applications, as well as the major challenges and future directions in disease modeling and cell-replacement therapy of AD.

\section{Progress of iPSCs research}

In 2006, Yamanaka and colleagues found mouse fibroblast cells can be reprogrammed into iPSCs by using 4 transcription factors including Octamer-binding transcription factor 4 (Oct4), sex determining region Y-box 2 (Sox2), Kruppel-like factor 4 and cMyc [30]. In 2007, this technology was successfully applied in human somatic cells [29]. Additionally, a combination of Oct4, Sox2, NANOG and LIN28 has also been demonstrated to induce iPSCs from human somatic cells [29, 31]. After the first discovery of mouse or human iPSCs, considerable efforts have been made to develop or optimize this technology, including reprogramming cells by using fewer or newly defined factors and more efficient delivery systems.

Oct4 inhibits the expression of differentiation-related genes in ESCs [34-36] and has been reported to be sufficient to direct the reprogramming of somatic cells into iPSCs [37, 38]. Moreover, Shu et al. have found that lineage specifiers, which act as pluripotency rivals to suppress ESCs identity, can induce mouse fibroblasts into iPSCs [39]. Lineage specifiers that are involved in 


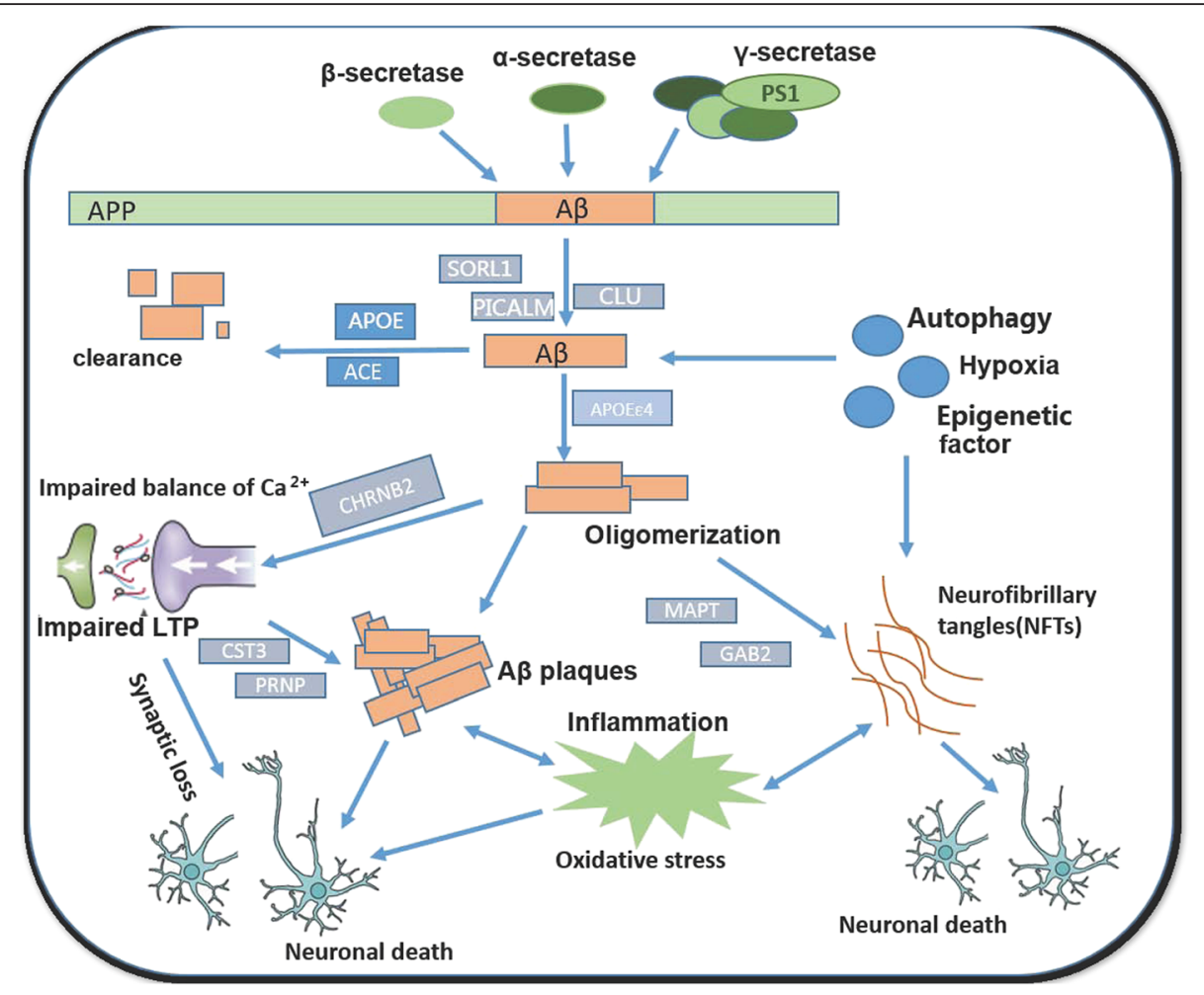

Fig. 1 Schematic diagram of causative or risk factors for AD pathogenesis

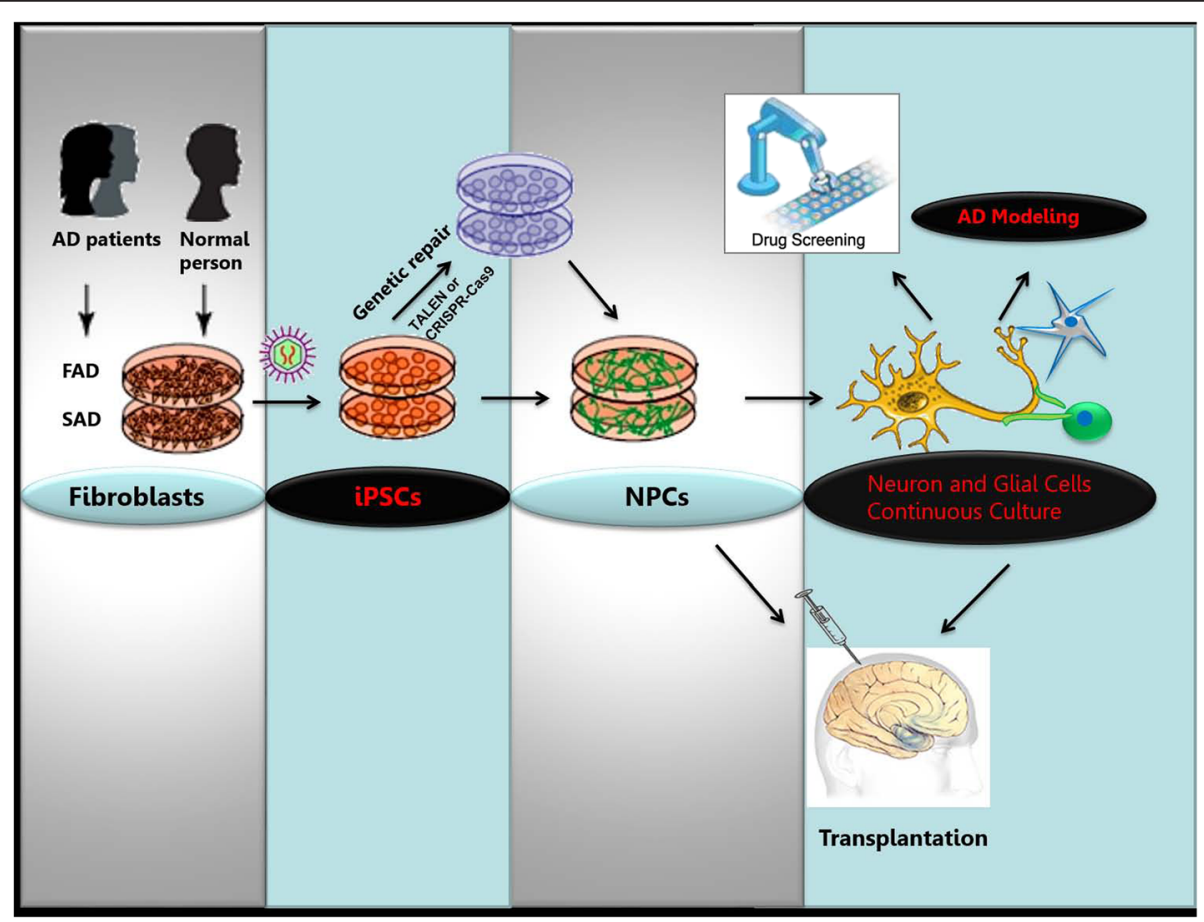

Fig. 2 Potential applications of iPSCs technology in AD modeling, drugs screening and cell-replacement therapy 
mesendodermal specification (such as GATA3, GATA6, and SOX7) and ectodermal specification (such as SOX1, SOX3, and GMNN) can synergistically induce pluripotency in the absence of Oct4 and Sox2, suggesting a "seesaw effect" of the lineage specifiers in cell reprogramming. Additionally, more and more novel reprogramming factors have been identified as pluripotency-associated factors or maternal factors, such as PR domain-containing 14, Sall4, Esrrb, Utf1, Tet1, Tet2, Gli-similar protein 1 and inhibitors of differentiation 3 [40-48].

Manipulations of microRNAs (miRs), such as miR291-3p, miR-294 and miR-295, have been reported to increase the efficiency of reprogramming without the presence of cMyc [49]. Anokye-Danso and colleagues have also found that miR-302-367 can replace traditional reprogramming factors to reprogram mouse and human somatic cells into iPSCs with higher efficiency [50].

Besides the utilization of pluripotency transcription factors, the induction of iPSCs has been extended to involve various kinds of donor cells, including fibroblasts, glias, neural progenitors, human keratinocytes, liver and stomach cells, pancreatic- $\beta$ cells, mature B lymphocytes, human amniotic fluid-derived cells, as well as cells in blood and urine [51-56].

Additionally, the delivering strategies for inducing iPSCs have been improved. The retroviral or lentiviral vectors were routinely used to integrate the reprogramming genes into the host genome to induce iPSCs [30, 57]. Viral delivery system are efficient and reproducible in reprogramming, however, the random integration of transgenes into genome increases the risk of tumor formation and may cause mortality in chimeric and progeny mice derived from iPSCs [58]. Transfection of linear DNA by polycistronic vectors using liposomes or electroporation can avoid viral integration, but the reprogramming efficiency of these methods is much lower than viral delivery. The piggyBac transposon delivery system is less risky because the integration of non-viral constructsis more stable than virus vectors [59]. Furthermore, many viral integrationfree systems for iPSCs generation have been established, such as adenovirus, Sendai virus, minicircle vector, episomal vectors, and direct protein delivery [60-65]. Importantly, Hou et al. have reported that small-molecules, such as VC6T plus FSK, can replace "master genes" Sox2 and Oct4 to induce cell reprogramming $[65,66]$. This chemical reprogramming strategy is relatively simple and less time-consuming, and has promising potential in generating functional desirable cell types for clinical applications.

\section{Application of iPSCs in AD modeling}

The rapid development of iPSCs technology promotes the application of iPSCs in the research of neurodegenerative diseases. Since 2008, over 50 literatures have been published to demonstrate the neurodegenerative diseases modeling by using iPSCs, majorly generated from familial patients but a few from sporadic patients [32]. Among them, several research groups have reported the usage of iPSCs in AD modeling, which provide proof-of-principle for modeling patient-specific $A D$ pathology by using iPSCs and recapitulate several pathological features of $\mathrm{AD}$ in vitro (Table 1).

Yagi et al. firstly generated iPSCs from AD patients carrying familial mutations in PSEN1 (A246E) and PSEN2 (N141I) and reported that these FAD-derived iPSCs had an increased $A \beta_{42}$ production and an elevated ratio of $A \beta_{42} / A \beta_{40}$ [67]. Then, Israel et al. generated iPSCs lines from two SAD patients (named as SAD1/ sAD2) and two FAD patients with a duplication of APP $\left(\mathrm{APP}^{\mathrm{Dp}}\right)$ [68]. They found that neurons derived from $\mathrm{APP}^{\mathrm{DP}}$-iPSCs line and sAD2-iPSCs line have significantly higher levels of $A \beta_{40}$, increased phosphorylation of tau protein (at Thr 231) together with an elevated level of

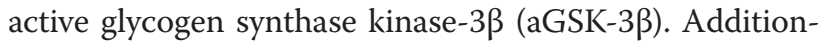
ally, neurons from those AD-derived iPSCs (AD-iPSCs) accumulated large RAB5-positive early endosomes, which is consistent with the findings from the neurons of $\mathrm{AD}$ patients [69]. More interestingly, treatment of the neurons with $\beta$-secretase inhibitors (BSI), but not $\gamma$-secretase inhibitors, could significantly reduce the levels of phospho-tau (Thr 231) and aGSK-3 $\beta$, while $\gamma$-secretase inhibitors only reduced the level of $A \beta_{40}$, suggesting that APP proteolytic processing, but not $A \beta_{40}$, had a direct relationship with GSK-3 $\beta$ activation and tau phosphorylation in human neurons. Consistent with these findings, Jang et al. and Shi et al. have also generated neurons from iPSCs derived from primary fibroblast of AD patients $[70,71]$ and found these cells could recapitulate AD pathogenic process such as $A \beta_{42}$ and hyperphosphorylated tau and could be used for screening new drugs and therapeutic regimens.

Sproul et al. also have found a higher $A \beta_{42} / A \beta_{40}$ ratio in the neural progenitor cells (NPCs) derived from ADiPSCs harboring PSEN1 A246E or M146L mutations [72]. Moreover, they identified 14 genes differentiallyregulated in PSEN1 NPCs molecular profiling. Among these genes, GFRA3, ISL1, DLX1, SEMA3B, and ERBB3 showed differential expression in late onset $\mathrm{AD} /$ Intermediate AD brains.

Kondo et al. generated seven AD-iPSCs lines, including three lines from a patient carrying APP E693 deletion (APP E693d), two lines from a patient harboring APP V717L mutation (APP V717L), and two lines from a SAD patient [73]. The authors found that $A \beta$ oligomers accumulated in neurons derived from APP E693diPSCs and in neurons and astrocytes derived from one of the two SAD-iPSCs lines, which could be reduced by BSI. Furthermore, they found that the stress responses 
Table 1 iPSCs-based AD modeling

\begin{tabular}{|c|c|c|c|c|}
\hline Cell type & AD models & Phenotypes & Significance & Ref \\
\hline FAD-iPSCs & $\begin{array}{l}\text { Fibroblasts of FAD } \\
\text { patient with mutations } \\
\text { in PS1 and PS2 }\end{array}$ & $\begin{array}{l}\text { FAD-iPSCs-derived neurons have } \\
\text { increased A } 342 \text { secretion; responds } \\
\text { to } \gamma \text {-secretase inhibitors and modulators }\end{array}$ & $\begin{array}{l}\text { Recapitulating the molecular pathogenesis } \\
\text { of mutant PS; identification and validation } \\
\text { of candidate drugs }\end{array}$ & [67] \\
\hline $\begin{array}{l}\text { FAD- and } \\
\text { SAD-iPSCs }\end{array}$ & $\begin{array}{l}\text { Fibroblasts of FAD } \\
\text { patient with mutations } \\
\text { in APP; sporadic AD }\end{array}$ & 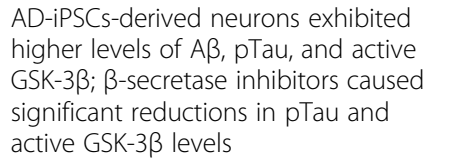 & $\begin{array}{l}\text { The first SAD iPSC model; Demonstrating } \\
\text { the direct relationship between APP } \\
\text { processing in GSK- } 3 \beta \text { activation and } \\
\text { tau phosphorylation }\end{array}$ & [68] \\
\hline AD-iPSCs & $\begin{array}{l}\text { Fibroblasts from AD } \\
\text { patient }\end{array}$ & AD-specific iPSCs lines & $\begin{array}{l}\text { Exploring AD pathologies; screening } \\
\text { new drugs and therapeutic regimens }\end{array}$ & [70] \\
\hline AD-iPSCs & $\begin{array}{l}\text { Fibroblast of Down } \\
\text { syndrome patients }\end{array}$ & $\begin{array}{l}\text { Neurons generated from Down } \\
\text { syndrome patients-iPSCs developed } \\
\text { AD pathologies }\end{array}$ & $\begin{array}{l}\text { Recapitulating AD pathogenic process } \\
\text { including } A \beta 42 \text { and hyperphosphorylated } \\
\text { tau }\end{array}$ & [71] \\
\hline FAD-iPSCs & $\begin{array}{l}\text { PSEN1 mutant } \\
\text { fibroblasts }\end{array}$ & $\begin{array}{l}\text { produced greater ratios of } A \beta 42 \text { to } \\
A \beta 40 ; 14 \text { genes differentially-regulated }\end{array}$ & $\begin{array}{l}\text { Identify novel candidate genes during } \\
\text { AD pathology }\end{array}$ & [72] \\
\hline FAD-iPSCs & \multirow{2}{*}{$\begin{array}{l}\text { Human dermal } \\
\text { fibroblasts }\end{array}$} & \multirow{2}{*}{$\begin{array}{l}\text { A } \beta \text { oligomers accumulation; elevated } \\
\text { endoplasmic reticulum (ER) and } \\
\text { oxidative stress; }\end{array}$} & \multirow{2}{*}{$\begin{array}{l}\text { Illustrating how patient-specific iPSCs } \\
\text { can be useful for analyzing AD } \\
\text { pathogenesis and evaluating drugs. }\end{array}$} & \multirow[t]{2}{*}{ [73] } \\
\hline SAD-iPSCs & & & & \\
\hline \multirow[t]{2}{*}{ FAD-iPSCs } & \multirow[t]{2}{*}{$\begin{array}{l}\text { Human fibroblast } \\
\text { carrying APP } \\
\text { mutation (V717l) }\end{array}$} & \multirow[t]{2}{*}{$\begin{array}{l}\text { Increased APP expression and levels } \\
\text { of APPs } \beta \text {, A } \beta \text {; increased } A \beta 42 \text { and } A \beta 38 ; \\
\text { increase in levels of total and } \\
\text { phosphorylated Tau }\end{array}$} & $\begin{array}{l}\text { Demonstrating the direct casual } \\
\text { relationship between elevated } A \beta \\
\text { and hyperphosphorylated tau using } \\
A \beta \text { neutralizing antibodies, for the } \\
\text { first time; }\end{array}$ & \multirow[t]{2}{*}{ [74] } \\
\hline & & & $\begin{array}{l}\text { Providing a model system for testing } \\
\text { therapeutic strategies in the cell types } \\
\text { most relevant to disease processes }\end{array}$ & \\
\hline
\end{tabular}

in the AD neural cells were alleviated by BSI and docosahexaenoic acid treatment. This study illustrates the possible application of patient-specific iPSCs for screening anti-AD drugs and classifying AD patients.

Muratore et al. generated four iPSCs lines from two FAD patients carrying APP V717I mutation and differentiated them into neurons expressing forebrain neuron marker [74]. Both $\beta$ - and $\gamma$-secretase cleavage of APP were affected by this mutation. Elevated $\beta$-secretase cleavage of APP led to an increased level of both SAPP $\beta$ and $A \beta$, while the alteration of the initial cleavage site of $\gamma$-secretase resulted in an increased $A \beta_{42}$ and $A \beta_{38}$. Moreover, they found that the levels of total and phosphorylated tau were increased in neurons derived from AD patient. Furthermore, A $\beta$-specific antibodies could reverse the phenotype of increased total tau in ADiPSCs derived neurons. These findings indicate that the tau-related changes are relevant to $\mathrm{A} \beta$ phenotype and the increased tau might be a consequence of $A \beta$ generation, which is consistent with the amyloid-cascade hypothesis of AD.

Furthermore, forebrain cholinergic neuron (FBCN) loss is directly relevant to the memory and cognition deficits in AD. Therefore, generation of FBCNs from AD patient-specific iPSCs is crucial for disease modeling in vitro and for the development of novel $\mathrm{AD}$ therapies. Based on this, Duan et al. have recently reported that
FBCNs derived from SAD-iPSCs showed typical AD biochemical features as evidenced by an increased $A \beta_{42} /$ $\mathrm{A} \beta_{40}$ ratio and a higher susceptibility to glutamatemediated cell death [75].

Down syndrome (DS) patients with early-onset dementia share similar neurodegenerative features with those of AD. Chang et al. have recently found that accumulated amyloid deposits, tau protein hyperphosphorylation and tau intracellular redistribution emerged rapidly in DS-iPSCs-derived neurons within 45 days but not in normal ESCs-derived neurons, suggesting DSiPSC-derived neural cells can serve as an ideal cellular model of DS and AD and have potential for highthroughput screening of therapeutic candidates [76].

\section{Challenges and future perspectives of iPSCs in AD disease modeling}

The above mentioned research findings reveal several pathological features of $\mathrm{AD}$, including $\mathrm{A} \beta$ generation and tau-phosphorylation, in AD-iPSCs derived from FAD and SAD patients, indicating the potential application of iPSCs technology in AD modeling and drug screening. However, there are still several concerns regarding AD-iPSCs models.

First of all, although iPSCs could serve as a promising avenue for disease modeling, the molecular principles for this technique, particularly in human cells, still 
remain poorly understood due to donor-to-donor variability and intercellular heterogeneity. In the study from Israel et al., only one of the two SAD-iPSCs lines has the same phenotypes as the $\mathrm{APP}^{\mathrm{DP}}$-iPSCs line. Similarly, Kondo et al. have also found that seven AD-iPSCs lines with APP E693 deletion or APP V717L mutation or SAD did not always recapitulate the same phenotypes [73]. These inconsistencies might suggest that although there are similar mechanisms underlying the pathogenesis of FAD or SAD, a larger sample size is still required to investigate the comprehensive and robust heterogeneity of $\mathrm{AD}$ phenotypes in future study. In addition, although $\mathrm{AD}$ patient-derived human neurons have shown elevated levels of toxic $A \beta$ species and phosphorylated tau, they also could not recapitulate $A \beta$ plaques or tau tangles. One of the possible reasons for this might be the lack of a proper cell culture system, which mimics the in vivo condition and provides a better microenvironment to achieve enough pathogenic $A \beta$ accumulation, as observed in human $\mathrm{AD}$ patients and transgenic $\mathrm{AD}$ mouse models. Recently, Kim et al. have found that robust $A \beta$ and tau pathologies could be achieved in a 3dimension human neural cell culture models [77]. Although this model was based on genetically engineered human neural stem cell line, not iPSCs, it may provide a promising tool for human AD iPSCs models.

Secondly, the neural cells differentiated from iPSCs displayed $\mathrm{AD}$ pathological hallmarks in less than two months, suggesting that disease-related cells may be more susceptible to display the hallmarks of disease in cell culture dishes than in patients' brains. However, there also remains the question that whether the one or two cell types differentiated from iPSCs can represent all complicate phenotypes of $\mathrm{AD}$. In addition, the cells exhibited the pathological changes of AD, but synapse loss or neuronal degeneration was rarely observed. It has been reported that $\mathrm{AD}$ is a complex disease that affects both neuronal and glial activities and glia participates in $\mathrm{A} \beta$ clearance and inflammation in AD [78]. Therefore, further studies of glial cells derived from AD-iPSCs can facilitate the discovery of the exact mechanisms underling $\mathrm{AD}$ pathogenesis.

Thirdly, in these studies of AD-iPSCs, iPSCs derived from healthy individuals or family members were used as controls, which may have totally different genetic background from the AD-iPSCs. This kind of controls is not the most appropriate approach in disease modeling assays. Hence, isogenic iPSCs derived from AD-iPSCs, in which the mutations have been corrected to wild-type, are the most appropriate controls. Nowadays, isogenic, mutation-corrected control cell lines generated by transcription activator-like effector nucleases (TALENs) or clustered regularly interspaced short palindromic repeats (CRISPR)/CRISPR-associated protein (Cas) mediated genomic editing technology has been applied in human diseases, such as ALS, and tumors [79, 80].

Overall, AD-iPSC lines from more $\mathrm{AD}$ patients and further studies using both AD-iPSC-derived neuron and glial cells and isogenic controls can provide tools to discover more accurate features and mechanisms of AD.

\section{iPSCs-based cell replacement therapy for AD: the mechanisms and rationales}

iPSCs have great potential in cell transplantation therapy of neurodegenerative diseases including AD. Transplantable neural progenitors or neurons can be generated from ESCs and iPSCs $[81,82]$. NPCs derived from ESCs or iPSCs can be further differentiated into neurons, astrocytes or oligodendrocytes, which provide promising aspect for cell-replacement therapy of various neurodegenerative disorders including $\mathrm{AD}$.

The dysfunction of neurogenesis has been found in $\mathrm{AD}$ mouse models, indicating that the worsened imbalance between neurogenesis and neuronal loss may contribute to the pathogenesis of $\mathrm{AD}$ [83]. It is generally accepted that adult neurogenesis primarily occurs in two sites important for learning and memory, the subventricular zone (SVZ) of the lateral ventricles and the subgranular zone (SGZ) of the dentate gyrus (DG) of the hippocampus. Wang et al. have reported that AD transgenic mice harboring PSEN1P117L show a decreased survival of NPCs, leading to a reduced production of new neurons. In addition, the reduced adult neurogenesis in DG has been suggested to be correlated with an impaired contextual fear conditioning in mouse [84-87]. In APP V717F mice, an age-dependent decrease of cell proliferation in SGZ of DG was also observed [88]. Research reports suggest that neurogenesis was significantly enhanced as a self-repairing mechanism to compensate for the early onset of neurodegeneration; however, the survival of newly generated neurons was impaired following neurodegeneration progression [89]. Interestingly, although the cellular composition and morphological organization of the SVZ in human and non-human primates differ from those of rodents [90, 91], the proliferation and migration of NPCs in the SVZ of young APP transgenic mice have also been reported to be greatly decreased [92], suggesting that $A \beta$ plaques might be involved in the impaired neurogenesis in AD mouse model. However, it has been reported that the decreased NPCs and neuroblasts as wells as severely impaired proliferation and differentiation of NPCs occurred preceding the onset of amyloid deposition and memory impairment in 2month-old APPswe/PSEN1 $\triangle \mathrm{E} 9$ mice or triple transgenic mice carrying APPswe, PSEN1-M146V and tau-P301L mutations [93]. These findings suggest that progressive neuronal loss and impaired neurogenesis may be important pathological events of $\mathrm{AD}$. 
Previous studies have found that transplanted NSCs differentiate into mature cell types and improve cognitive ability of $\mathrm{AD}$ animal models via various mechanisms, with or without the involvement of $A \beta$ or tau pathologies. For instance, NSCs have been reported to rescue cognitive functions and promote synaptogenesis without altering $\mathrm{A} \beta$ or tau pathologies in AD mouse models [94-96]. Moreover, NSCs have also been found to attenuate the expression of proinflammatory cytokines and neuronal loss in $\mathrm{AD}$ model [97]. In contrast to these research reports, Lee et al. have revealed that human NSCs transplantation reduced tau phosphorylation, down-regulated $\mathrm{BACE} 1$ expression and $\mathrm{A} \beta$ production via Akt/GSK3 $\beta$ signaling, and decreased the expression of inflammatory mediators through deactivation of microglia [98]. As a primary source of NSCs, iPSCs, especially humanderived iPSCs, may provide a promising strategy for cell-replacement therapy of AD.

It is likely that the transplantation of NSCs can provide not only a direct cell-replacing strategy for AD therapy, but also can be used as vehicles for the delivery of potential therapeutic agents, including neprilysin, insulindegrading enzyme, plasmin and cathepsin $\mathrm{B}$, to reverse AD pathologies [99, 100]. It is suggested that the future NSCs- or iPSCs-based cell therapy in AD should focus on such indirect mechanisms [101-103].

\section{iPSCs-based cell replacement therapy for AD: hints from other CNS disorders}

iPSCs have great potential as cell source in cell transplantation therapy of neurodegenerative diseases [104, 105]. One of the main purposes of iPSCs-based cell replacement therapy in $\mathrm{AD}$ and other neurodegenerative diseases is to produce new neurons to replace those lost or functiondeficient cells during disease progression or to produce glial cells to protect neurons from ongoing degeneration. Data from in vivo studies suggest that iPSCs-derived neurospheres were able to survive and differentiate into neurons, astrocytes, and oligodendrocytes, after transplantation into injured mouse spinal cord [106]. In addition, previous research report has also indicated that after transplantation into the fetal mouse brain, NPCs derived from mouse iPSCs migrate into various brain regions and differentiate into glia and neurons [107], and thus are capable to integrate into preexisting functional neuronal circuitries in the CNS or compensate the degenerative neurons. Electrophysiological experiments and morphological observations demonstrate that the grafted neurons display normal neuronal activity and are functionally integrated into the host brain. All these findings support the notion that iPSCs- or iPSCs derivatives-based cell replacement therapy could be efficiently used to treat neurodegenerative diseases. Indeed, several lines of studies have tested this idea in experimental models of Parkinson's disease (PD) and amyotrophic lateral sclerosis (ALS).

It has been reported that transplanted neural stem cells in parkinsonian rat striatum can release and reuptake dopamine and alleviate PD symptoms [108]. Human iPSCs-derived neurons can improve the functional defects of rotational asymmetry in PD rat model after transplantation [109]. Autologous iPSCs-derived dopamine neurons can provide long-term functional recovery in monkey model of PD [84]. In addition, glial-rich neural progenitors derived from human iPSCs can improve lifespan of ALS mice after being transplanted into the lumbar spinal cord [85].

As for $\mathrm{AD}$, Fujiwara et al. have reported that the spatial memory of AD mice was improved significantly after grafted with human iPSCs-derived neural progenitors [110]. In addition, Huang's group has found that after transplantation of the embryonic medial ganglionic eminence (MGE)-derived interneuron progenitors into the hippocampal hilus of aged apoE4-KI mice, the transplanted cells developed into mature interneurons, and the neurons functionally integrated into the hippocampal circuitry and rescued learning and memory [111]. Moreover, Nicholas et al. found that MGE-like progenitors derived from both ESCs and iPSCs could be induced to differentiate into GABAergic interneurons and displayed mature physiological properties in mouse brain up to 7 months post-transplantation [112]. These research findings indicate that transplanted human iPSCsderived cells can functionally rescue pathological changes in the brains of AD patients. All these preclinical progresses in the investigation of cell transplantation in neurodegenerative diseases may provide proof-ofconcept for the final clinical translation of iPSCs in therapy of AD.

Although great achievements have been made for iPSCs-based cell replacement therapy, one major challenge is teratoma formation. It has been demonstrated in the mouse system that iPSCs-derived chimeras frequently develop tumors, which should be carefully evaluated after transplantation before clinical application. Takahashi et al. calculated that approximately $20 \%$ of the mice derived from iPSCs develop tumors [113]. Transgene reactivation and incomplete reprogramming are considered as the primary causes of tumorigenesis [114]. In order to reduce the risk of tumor formation that limits the clinic application of iPSCs, many studies have provided strategies. Wang et al. have introduced a mifepristone-regulated caspase-1 expression system to selectively eliminate tumor cells derived from undifferentiated ESCs but not differentiated dopamine neurons [115]. Cui et al. have identified that the suppression of canonical wingless-type MMTV integration site family (WNT) signaling pathway can reduce the tumorigenicity 
and substantially improved retinal integration of ESCsderived retinal progenitor cells transplanted in mice [116]. In addition, Nori et al. have recently suggested that integration-free iPSCs should be chosen to avoid tumorigenesis [117]. Overall, these progresses of iPSCs research can provide new avenue for the clinical translation of cell transplantation therapy against various neurodegenerative diseases including $\mathrm{AD}$.

\section{Conclusion}

AD patient-specific iPSCs-derived neurons or glia cells can recapture not only familial, but also sporadic form of AD. Moreover, iPSCs provide unique platforms to detect the early-disease phenotypes during neurogenesis or neurodegeneration which may point towards underlying pathogenic mechanisms of $\mathrm{AD}$. In addition, isogenic iPSCs of AD-iPSCs can be obtained by TALEN- or CRISPR/Casmediated genetic repairing technology. Genetically repaired AD-iPSCs can serve as more appropriate control cells for disease modeling and cells transplantation. Altogether, even though there are several challenges in the clinical usage of iPSCs technology, the recent promising achievements in this field will contribute significantly for exploring molecular mechanisms of $\mathrm{AD}$ and promoting clinical AD therapy.

\section{Abbreviations

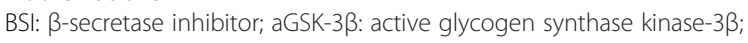 AD: Alzheimer's disease; $A \beta$ : Amyloid- $\beta$ (A $\beta$ ); APP: Amyloid precursor protein; APOE: Apolipoprotein E; CRISPR: Clustered regularly interspaced short palindromic repeats; Cas: CRISPR-associated protein; DG: Dentate gyrus; DS: Down syndrome; APPDP: Duplication of APP; ESCs: Embryonic stem cells; FAD: Familial AD; FBCN: Forebrain cholinergic neuron; iPSCs: Induced pluripotent stem cells; miRs: microRNAs; NMDA: N-methyl-D-aspartate; NPCs: Neural progenitor cells; NFTs: Neurofibrillary tangles; Oct4: Octamer-binding transcription factor 4; PSEN1/2: Presenilin-1/2; Sox: Sex determining region Y-box; SAD: Sporadic AD; TALENs: Transcription activator-like effector nucleases; SGZ: Subgranular zone; SVZ: Subventricular zone.}

\section{Competing interests}

The authors declare no competing interests.

\section{Authors' contributions}

WL proposed the writing of the review paper. JY, SL and CC wrote and revised the manuscript. JY and SL constructed the schematic diagrams. $\mathrm{XBH}$, $S L$ and $W L$ discussed and revised the manuscript. All authors read and approved the final manuscript.

\section{Acknowledgments}

This work was supported by grants from the National Natural Sciences Foundation of China (81430021 and 81370470), the Program for Liaoning Innovative Research Team in University (LT2015009).

\section{Author details}

${ }^{1}$ Center for Translational Research on Neurological Diseases, the First Affiliated Hospital, Dalian Medical University, 116021 Dalian, China. ${ }^{2}$ Key Laboratory of Stem Cell Biology, Institute of Health Sciences, Shanghai Institutes for Biological Sciences, Chinese Academy of Sciences/Shanghai Jiao Tong University School of Medicine, 200031 Shanghai, China. ${ }^{3}$ Collaborative Innovation Center for Brain Science, the First Affiliated Hospital, Dalian Medical University, 116011 Dalian, China. ${ }^{4}$ Shanghai University of Medicine and Health Sciences, Shanghai 201318, China.
Received: 3 December 2015 Accepted: 12 May 2016

Published online: 17 May 2016

\section{References}

1. Braak H, Braak E. Neuropathological stageing of Alzheimer-related changes. Acta Neuropathol. 1991;82(4):239-59.

2. Robakis NK. Cell signaling abnormalities may drive neurodegeneration in familial Alzheimer disease. Neurochem Res. 2014;39(3):570-5.

3. Roberson ED, Mucke L. 100 years and counting: prospects for defeating Alzheimer's disease. Science. 2006;314(5800):781-4.

4. Kumar A, Singh A, Ekavali. A review on Alzheimer's disease pathophysiology and its management: an update. Pharmacol Rep. 2015;67(2):195-203.

5. Serretti A, Olgiati $P$, De Ronchi D. Genetics of Alzheimer's disease. A rapidly evolving field. J Alzheimers Dis. 2007;12(1):73-92.

6. Hardy JA, Higgins GA. Alzheimer's disease: the amyloid cascade hypothesis. Science. 1992;256(5054):184-5.

7. Maccioni RB, Farias G, Morales I, Navarrete L. The revitalized tau hypothesis on Alzheimer's disease. Arch Med Res. 2010;41(3):226-31.

8. Swerdlow RH, Burns JM, Khan SM. The Alzheimer's disease mitochondrial cascade hypothesis: progress and perspectives. Biochim Biophys Acta. 2014;1842(8):1219-31.

9. Praticò D. Oxidative stress hypothesis in Alzheimer's disease: a reappraisal. Trends Pharmacol Sci. 2008;29(12):609-15.

10. Heppner FL, Ransohoff RM, Becher B. Immune attack: the role of inflammation in Alzheimer disease. Nat Rev Neurosci. 2015;16(6):358-72.

11. Salloway S, Sperling R, Fox NC, Blennow K, Klunk W, Raskind M, Sabbagh M, Honig LS, Porsteinsson AP, Ferris S, Reichert M, Ketter N, Nejadnik B, Guenzler V, Miloslavsky M, Wang D, Lu Y, Lull J, Tudor IC, Liu E, Grundman M, Yuen E, Black R, Brashear HR. Bapineuzumab 301 and 302 Clinical Trial Investigators. Two phase 3 trials of bapineuzumab in mild-to-moderate Alzheimer's disease. N Engl J Med. 2014:370(4):322-33.

12. Doody RS, Thomas RG, Farlow M, Iwatsubo T, Vellas B, Joffe S, Kieburtz K, Raman R, Sun X, Aisen PS, Siemers E, Liu-Seifert H, Mohs R, Alzheimer's Disease Cooperative Study Steering Committee; Solanezumab Study Group. Phase 3 trials of solanezumab for mild-to-moderate Alzheimer's disease. N Engl J Med. 2014;370(4):311-21.

13. Lippa CF, Swearer JM, Kane KJ, Nochlin D, Bird TD, Ghetti B, Nee LE, St George-Hyslop P, Pollen DA, Drachman DA. Familial Alzheimer's disease: site of mutation influences clinical phenotype. Ann Neurol. 2000;48(3): $376-9$.

14. Michaelson DM. APOE epsilon4: the most prevalent yet understudied risk factor for Alzheimer's disease. Alzheimers Dement. 2014;10(6):861-8.

15. Karch CM, Goate AM. Alzheimer's disease risk genes and mechanisms of disease pathogenesis. Biol Psychiatry. 2015;77(1):43-51.

16. Gatz M, Reynolds CA, Fratiglioni L, Johansson B, Mortimer JA, Berg S, Fiske A, Pedersen NL. Role of genes and environments for explaining Alzheimer disease. Arch Gen Psychiatry. 2006;63(2):168-74.

17. Sleegers K, Van Duijn CM. Alzheimer's Disease: Genes Pathogenesis and Risk Prediction. Community Genet. 2001;4(4):197-203.

18. Willette AA, Bendlin BB, Starks EJ, Birdsill AC, Johnson SC, Christian BT, Okonkwo OC, La Rue A, Hermann BP, Koscik RL, Jonaitis EM, Sager MA, Asthana S.. Association of insulin resistance with cerebral glucose uptake in late middle-aged adults at risk for Alzheimer Disease. JAMA Neurol. 2015;72(9):1013-20.

19. Hernandez-Zimbron LF, Rivas-Arancibia S. Oxidative stress caused by ozone exposure induces beta-amyloid 1-42 overproduction and mitochondrial accumulation by activating the amyloidogenic pathway. Neuroscience. 2015; 304:340-8.

20. Liu H, Qiu H, Yang J, Ni J, Le W. Chronic hypoxia facilitates Alzheimer's disease through demethylation of gamma-secretase by downregulating DNA methyltransferase 3b. Alzheimers Dement. 2016; 12(2):130-43.

21. Coupland KG, Kim WS, Halliday GM, Hallupp M, Dobson-Stone C, Kwok JB. Effect of PSEN1 mutations on MAPT methylation in early-onset Alzheimer's disease. Curr Alzheimer Res. 2015;12(8):745-51.

22. Li L, Zhang S, Zhang X, Li T, Tang Y, Liu H, Yang W, Le W. Autophagy enhancer carbamazepine alleviates memory deficits and cerebral amyloidbeta pathology in a mouse model of Alzheimer's disease. Curr Alzheimer Res. 2013;10(4):433-41. 
23. Ju YE, Lucey BP, Holtzman DM. Sleep and Alzheimer disease pathology-a bidirectional relationship. Nat Rev Neurol. 2014;10(2):115-9.

24. Webster SJ, Bachstetter AD, Nelson PT, Schmitt FA, Van Eldik LJ. Using mice to model Alzheimer's dementia: an overview of the clinical disease and the preclinical behavioral changes in 10 mouse models. Front Genet. 2014:5:88.

25. Bilkei-Gorzo A. Genetic mouse models of brain ageing and Alzheimer's disease. Pharmacol Ther. 2014;142(2):244-57.

26. Kim TK, Lee JE, Park SK, Lee KW, Seo JS, Im JY, Kim ST, Lee JY, Kim YH, Lee JK, Han PL. Analysis of differential plaque depositions in the brains of Tg2576 and Tg-APPswe/PS1dE9 transgenic mouse models of Alzheimer disease. Exp Mol Med. 2012;44(8):492-502.

27. Kitazawa M, Medeiros R, Laferla FM. Transgenic mouse models of Alzheimer disease: developing a better model as a tool for therapeutic interventions. Curr Pharm Des. 2012;18(8):1131-47.

28. Kuhn HG, Cooper-Kuhn CM, Boekhoorn K, Lucassen PJ. Changes in neurogenesis in dementia and Alzheimer mouse models: are they functionally relevant? Eur Arch Psychiatry Clin Neurosci. 2007;257(5):281-9.

29. Yu J, Vodyanik MA, Smuga-Otto K, Antosiewicz-Bourget J, Frane JL, Tian S, Nie J, Jonsdottir GA, Ruotti V, Stewart R, Slukvin II, Thomson JA. Induced pluripotent stem cell lines derived from human somatic cells. Science. 2007; 318(5858):1917-20.

30. Takahashi K, Yamanaka S. Induction of pluripotent stem cells from mouse embryonic and adult fibroblast cultures by defined factors. Cell. 2006;126(4): 663-76.

31. Takahashi K, Tanabe K, Ohnuki M, Narita M, Ichisaka T, Tomoda K, Yamanaka S. Induction of pluripotent stem cells from adult human fibroblasts by defined factors. Cell. 2007;131(5):861-72.

32. Hargus $G$, Ehrlich M, Hallmann AL, Kuhlmann T. Human stem cell models of neurodegeneration: a novel approach to study mechanisms of disease development. Acta Neuropathol. 2014;127(2): 151-73.

33. Bellin M, Marchetto MC, Gage FH, Mummery CL. Induced pluripotent stem cells: the new patient? Nat Rev Mol Cell Biol. 2012;13(11):713-26.

34. Kim JB, Zaehres H, Wu G, Gentile L, Ko K, Sebastiano V, Arauzo-Bravo MJ, Ruau D, Han DW, Zenke M, Scholer HR. Pluripotent stem cells induced from adult neural stem cells by reprogramming with two factors. Nature. 2008; 454(7204):646-50.

35. Pardo M, Lang B, Yu L, Prosser H, Bradley A, Babu MM, Choudhary J. An expanded Oct4 interaction network: implications for stem cell biology, development, and disease. Cell Stem Cell. 2010;6(4):382-95.

36. Chen SM, Lee MS, Chang CY, Lin SZ, Cheng EH, Liu YH, Pan HC, Lee HC, Su HL. Prerequisite OCT4 maintenance potentiates the neural induction of differentiating human embryonic stem cells and induced pluripotent stem cells. Cell Transplant. 2015;24(5):829-44.

37. Krohne TU, Westenskow PD, Kurihara T, Friedlander DF, Lehmann M, Dorsey AL, Li W, Zhu S, Schultz A, Wang J, Siuzdak G, Ding S, Friedlander M. Generation of retinal pigment epithelial cells from small molecules and OCT4 reprogrammed human induced pluripotent stem cells. Stem Cells Transl Med. 2012;1(2):96-109.

38. Li Y, Zhang Q, Yin X, Yang W, Du Y, Hou P, Ge J, Liu C, Zhang W, Zhang X, Wu Y, Li H, Liu K, Wu C, Song Z, Zhao Y, Shi Y, Deng H. Generation of iPSCs from mouse fibroblasts with a single gene, Oct4, and small molecules. Cell Res. 2011;21(1):196-204.

39. Shu J, Wu C, Wu Y, Li Z, Shao S, Zhao W, Tang X, Yang H, Shen L, Zuo X, Yang W, Shi Y, Chi X, Zhang H, Gao G, Shu Y, Yuan K, He W, Tang C, Zhao Y,

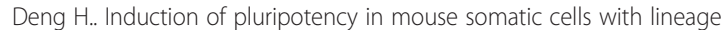
specifiers. Cell. 2013;153(5):963-75.

40. Nakagawa M, Koyanagi M, Tanabe K, Takahashi K, Ichisaka T, Aoi T, Okita K, Mochiduki Y, Takizawa N, Yamanaka S. Generation of induced pluripotent stem cells without Myc from mouse and human fibroblasts. Nat Biotechnol. 2008;26(1):101-6.

41. Aoi T. Advance in study of induced pluripotent stem cells (iPS cells). Nihon Rinsho. 2008;66(5):850-6.

42. Buganim $Y$, Jaenisch $R$. Transdifferentiation by defined factors as a powerful research tool to address basic biological questions. Cell Cycle. 2012;11(24):4485-6.

43. Chia NY, Chan YS, Feng B, Lu X, Orlov YL, Moreau D, Kumar P, Yang L, Jiang J, Lau MS, Huss M, Soh BS, Kraus P, Li P, Lufkin T, Lim B, Clarke ND, Bard F, $\mathrm{Ng} \mathrm{HH}$. A genome-wide RNAi screen reveals determinants of human embryonic stem cell identity. Nature. 2010;468(7321):316-20.
44. Doege CA, Inoue K, Yamashita T, Rhee DB, Travis S, Fujita R, Guarnieri P, Bhagat G, Vanti WB, Shih A, Levine RL, Nik S, Chen El, Abeliovich A. Early-stage epigenetic modification during somatic cell reprogramming by Parp1 and Tet2. Nature. 2012;488(7413):652-5.

45. Maherali N, Ahfeldt T, Rigamonti A, Utikal J, Cowan C, Hochedlinger K. A high-efficiency system for the generation and study of human induced pluripotent stem cells. Cell Stem Cell. 2008;3(3):340-5.

46. Hu X, Zhang L, Mao SQ, Li Z, Chen J, Zhang RR, Wu HP, Gao J, Guo F, Liu W, Xu GF, Dai HQ, Shi YG, Li X, Hu B, Tang F, Pei D, Xu GL. Tet and TDG mediate DNA demethylation essential for mesenchymal-to-epithelial transition in somatic cell reprogramming. Cell Stem Cell. 2014;14(4):512-22.

47. Moon JH, Heo JS, Kwon S, Kim J, Hwang J, Kang PJ, Kim A, Kim HO, Whang KY, Yoon BS, You S. Two-step generation of induced pluripotent stem cells from mouse fibroblasts using Id3 and Oct4. J Mol Cell Biol. 2012;4(1):59-62.

48. Chen J, Gao Y, Huang H, Xu K, Chen X, Jiang Y, Li H, Gao S, Tao Y, Wang H, Zhang $Y$, Wang H, Cai T, Gao S. The combination of Tet1 with Oct4 generates high-quality mouse-induced pluripotent stem cells. Stem Cells. 2015;33(3):686-98.

49. Judson RL, Babiarz JE, Venere M, Blelloch R. Embryonic stem cell-specific microRNAs promote induced pluripotency. Nat Biotechnol. 2009;27(5):459-61.

50. Anokye-Danso F, Trivedi CM, Juhr D, Gupta M, Cui Z, Tian Y, Zhang Y, Yang W, Gruber PJ, Epstein JA, Morrisey EE. Highly efficient miRNA-mediated reprogramming of mouse and human somatic cells to pluripotency. Cell Stem Cell. 2011;8(4):376-88.

51. Tsai SY, Clavel C, Kim S, Ang YS, Grisanti L, Lee DF, Kelley K, Rendl M.. Oct4 and klf4 reprogram dermal papilla cells into induced pluripotent stem cells. Stem Cells. 2010;28(2):221-8.

52. Watanabe S, Hirai H, Asakura Y, Tastad C, Verma M, Keller C, Dutton JR, Asakura A.. MyoD gene suppression by Oct4 is required for reprogramming in myoblasts to produce induced pluripotent stem cells. Stem Cells. 2011; 29(3):505-16.

53. Montserrat N, Ramirez-Bajo MJ, Xia Y, Sancho-Martinez I, Moya-Rull D, Miquel-Serra L, Yang S, Nivet E, Cortina C, Gonzalez F, Izpisua Belmonte JC, Campistol JM. Generation of induced pluripotent stem cells from human renal proximal tubular cells with only two transcription factors, OCT4 and SOX2. J Biol Chem. 2012;287(29):24131-8.

54. Meng X, Neises A, Su RJ, Payne KJ, Ritter L, Gridley DS, Wang J, Sheng M, Lau KH, Baylink DJ, Zhang XB. Efficient reprogramming of human cord blood CD34+ cells into induced pluripotent stem cells with OCT4 and SOX2 alone. Mol Ther. 2012;20(2):408-16.

55. Zhou T, Benda C, Duzinger S, Huang Y, Li X, Li Y, Guo X, Cao G, Chen S, Hao L, Chan YC, Ng KM, Ho JC, Wieser M, Wu J, Redl H, Tse HF, Grillari J, GrillariVoglauer R, Pei D, Esteban MA. Generation of induced pluripotent stem cells from urine. J Am Soc Nephrol. 2011;22(7):1221-8.

56. Stadtfeld M, Brennand K, Hochedlinger K. Reprogramming of pancreatic beta cells into induced pluripotent stem cells. Curr Biol. 2008;18(12):890-4.

57. Sommer AG, Rozelle SS, Sullivan S, Mills JA, Park SM, Smith BW, lyer AM, French DL, Kotton DN, Gadue P, Murphy GJ, Mostoslavsky G. Generation of human induced pluripotent stem cells from peripheral blood using the STEMCCA lentiviral vector. J Vis Exp. 2012;(68). doi: 10.3791/4327

58. Okita K, Ichisaka T, Yamanaka S. Generation of germline-competent induced pluripotent stem cells. Nature. 2007:448(7151):313-7.

59. Urschitz J, Kawasumi M, Owens J, Morozumi K, Yamashiro H, Stoytchev I, Marh J, Dee JA, Kawamoto K, Coates CJ, Kaminski JM, Pelczar P, Yanagimachi R, Moisyadi S. Helper-independent piggyBac plasmids for gene delivery approaches: strategies for avoiding potential genotoxic effects. Proc Natl Acad Sci U S A. 2010;107(18):8117-22.

60. Fink KD, Rossignol J, Lu M, Leveque X, Hulse TD, Crane AT, Nerriere-Daguin V, Wyse RD, Starski PA, Schloop MT, Dues DJ, Witte SJ, Song C, Vallier L, Nguyen TH, Naveilhan P, Anegon I, Lescaudron L, Dunbar GL. Survival and differentiation of adenovirus-generated induced pluripotent stem cells transplanted into the rat striatum. Cell Transplant. 2014;23(11):1407-23.

61. Stadtfeld M, Nagaya M, Utikal J, Weir G, Hochedlinger K. Induced pluripotent stem cells generated without viral integration. Science. 2008; 322(5903):945-9.

62. Woltjen K, Michael IP, Mohseni P, Desai R, Mileikovsky M, Hamalainen R, Cowling R, Wang W, Liu P, Gertsenstein M, Kaji K, Sung HK, Nagy A. piggyBac transposition reprograms fibroblasts to induced pluripotent stem cells. Nature. 2009;458(7239):766-70.

63. Li M, Izpisua Belmonte JC. No factor left behind: generation of transgene-free induced pluripotent stem cells. Am J Stem Cells. 2011;1(1):75-80. 
64. Piao Y, Hung SS, Lim SY, Wong RC, Ko MS. Efficient generation of integrationfree human induced pluripotent stem cells from keratinocytes by simple transfection of episomal vectors. Stem Cells Transl Med. 2014;3(7):787-91.

65. Zhou H, Wu S, Joo JY, Zhu S, Han DW, Lin T, Trauger S, Bien G, Yao S, Zhu Y, Siuzdak G, Schöler HR, Duan L, Ding S. Generation of induced pluripotent stem cells using recombinant proteins. Cell Stem Cell. 2009;4(5):381-4.

66. Hou P, Li Y, Zhang X, Liu C, Guan J, Li H, Zhao T, Ye J, Yang W, Liu K, Ge J, Xu J, Zhang Q, Zhao Y, Deng $H$. Pluripotent stem cells induced from mouse somatic cells by small-molecule compounds. Science. 2013;341(6146):651-4.

67. Yagi T, Ito D, Okada Y, Akamatsu W, Nihei Y, Yoshizaki T, Yamanaka S, Okano $H$, Suzuki N. Modeling familial Alzheimer's disease with induced pluripotent stem cells. Hum Mol Genet. 2011;20(23):4530-9.

68. Israel MA, Yuan SH, Bardy C, Reyna SM, Mu Y, Herrera C, Hefferan MP, Van Gorp S, Nazor KL, Boscolo FS, Carson CT, Laurent LC, Marsala M, Gage FH, Remes AM, Koo EH, Goldstein LS. Probing sporadic and familial Alzheimer's disease using induced pluripotent stem cells. Nature. 2012;482(7384):216-20.

69. Cataldo AM, Peterhoff CM, Troncoso JC, Gomez-Isla T, Hyman BT, Nixon RA. Endocytic pathway abnormalities precede amyloid beta deposition in sporadic Alzheimer's disease and Down syndrome: differential effects of APOE genotype and presenilin mutations. Am J Pathol. 2000;157(1):277-86.

70. Jang J, Yoo JE, Lee JA, Lee DR, Kim JY, Huh YJ, Kim DS, Park CY, Hwang DY, Kim HS, Kang HC, Kim DW. Disease-specific induced pluripotent stem cells: a platform for human disease modeling and drug discovery. Exp Mol Med. 2012;44(3):202-13.

71. Shi Y, Kirwan P, Smith J, MacLean G, Orkin SH, Livesey FJ. A human stem cell model of early Alzheimer's disease pathology in Down syndrome. Sci Transl Med. 2012;4(124):124ra29.

72. Sproul AA, Jacob S, Pre D, Kim SH, Nestor MW, Navarro-Sobrino M, SantaMaria I, Zimmer M, Aubry S, Steele JW, Kahler DJ, Dranovsky A, Arancio O, Crary JF, Gandy S, Noggle SA. Characterization and molecular profiling of PSEN1 familial Alzheimer's disease iPSC-derived neural progenitors. PLoS One. 2014;9(1):e84547.

73. Kondo T, Asai M, Tsukita K, Kutoku Y, Ohsawa Y, Sunada Y, Imamura K, Egawa N, Yahata N, Okita K, Takahashi K, Asaka I, Aoi T, Watanabe A, Watanabe K, Kadoya C, Nakano R, Watanabe D, Maruyama K, Hori O, Hibino S, Choshi T, Nakahata T, Hioki H, Kaneko T, Naitoh M, Yoshikawa K, Yamawaki S, Suzuki S, Hata R, Ueno S, Seki T, Kobayashi K, Toda T, Murakami K, Irie K, Klein WL, Mori H, Asada T, Takahashi R, Iwata N, Yamanaka S, Inoue H.. Modeling Alzheimer's disease with iPSCs reveals stress phenotypes associated with intracellular Abeta and differential drug responsiveness. Cell Stem Cell. 2013;12(4):487-96.

74. Muratore CR, Rice HC, Srikanth P, Callahan DG, Shin T, Benjamin LN, Walsh DM, Selkoe DJ, Young-Pearse TL. The familial Alzheimer's disease APPV717I mutation alters APP processing and Tau expression in iPSC-derived neurons. Hum Mol Genet. 2014;23(13):3523-36.

75. Duan L, Bhattacharyya BJ, Belmadani A, Pan L, Miller RJ, Kessler JA. Stem cell derived basal forebrain cholinergic neurons from Alzheimer's disease patients are more susceptible to cell death. Mol Neurodegener. 2014;9:3.

76. Chang CY, Chen SM, Lu HE, Lai SM, Lai PS, Shen PW, Chen PY, Shen CI, Harn HJ, Lin SZ, Hwang SM, Su HL.. N-butylidenephthalide attenuates Alzheimer's disease-like cytopathy in Down syndrome induced pluripotent stem cell-derived neurons. Sci Rep. 2015;5:8744.

77. Choi SH, Kim YH, Hebisch M, Sliwinski C, Lee S, D'Avanzo C, Chen H, Hooli B, Asselin C, Muffat J, Klee JB, Zhang C, Wainger BJ, Peitz M, Kovacs DM, Woolf CJ, Wagner SL, Tanzi RE, Kim DY. A three-dimensional human neural cell culture model of Alzheimer's disease. Nature. 2014;515(7526):274-8.

78. Solito E, Sastre M. Microglia function in Alzheimer's disease. Front Pharmacol. 2012;3:14.

79. Chen H, Qian K, Du Z, Cao J, Petersen A, Liu H, Blackbourn LW, Huang CL, Errigo A, Yin Y, Lu J, Ayala M, Zhang SC. Modeling ALS with iPSCs reveals that mutant SOD1 misregulates neurofilament balance in motor neurons. Cell Stem Cell. 2014;14(6):796-809.

80. Chen S, Sanjana NE, Zheng K, Shalem O, Lee K, Shi X, Scott DA, Song J, Pan $J Q$, Weissleder R, Lee H, Zhang F, Sharp PA. Genome-wide CRISPR screen in a mouse model of tumor growth and metastasis. Cell. 2015;160(6):1246-60.

81. Klincumhom N, Pirity MK, Berzsenyi S, Ujhelly O, Muenthaisong S, Rungarunlert S, Tharasanit T, Techakumphu M, Dinnyes A. Generation of neuronal progenitor cells and neurons from mouse sleeping beauty transposongenerated induced pluripotent stem cells. Cell Reprogram. 2012;14(5):390-7.

82. Sareen D, Gowing G, Sahabian A, Staggenborg K, Paradis R, Avalos P, Latter J, Ornelas L, Garcia L, Svendsen CN. Human induced pluripotent stem cells are a novel source of neural progenitor cells (iNPCs) that migrate and integrate in the rodent spinal cord. J Comp Neurol. 2014;522(12):2707-28.

83. Haughey NJ, Liu D, Nath A, Borchard AC, Mattson MP. Disruption of neurogenesis in the subventricular zone of adult mice, and in human cortical neuronal precursor cells in culture, by amyloid beta-peptide: implications for the pathogenesis of Alzheimer's disease. Neuromolecular Med. 2002;1(2):125-35.

84. Hallett PJ, Deleidi M, Astradsson A, Smith GA, Cooper O, Osborn TM, Sundberg M, Moore MA, Perez-Torres E, Brownell AL, Schumacher JM, Spealman RD, Isacson O. Successful function of autologous iPSC-derived dopamine neurons following transplantation in a non-human primate model of Parkinson's disease. Cell Stem Cell. 2015;16(3):269-74.

85. Kondo T, Funayama M, Tsukita K, Hotta A, Yasuda A, Nori S, Kaneko S, Nakamura M, Takahashi R, Okano H, Yamanaka S, Inoue H. Focal transplantation of human iPSC-derived glial-rich neural progenitors improves lifespan of ALS mice. Stem Cell Reports. 2014;3(2):242-9.

86. Wang R, Dineley KT, Sweatt JD, Zheng H. Presenilin 1 familial Alzheimer's disease mutation leads to defective associative learning and impaired adult neurogenesis. Neuroscience. 2004;126(2):305-12.

87. Wen PH, Hof PR, Chen X, Gluck K, Austin G, Younkin SG, Younkin LH, DeGasperi R, Gama Sosa MA, Robakis NK, Haroutunian V, Elder GA. The presenilin-1 familial Alzheimer disease mutant P117L impairs neurogenesis in the hippocampus of adult mice. Exp Neurol. 2004;188(2):224-37.

88. Donovan MH, Yazdani U, Norris RD, Games D, German DC, Eisch AJ. Decreased adult hippocampal neurogenesis in the PDAPP mouse model of Alzheimer's disease. J Comp Neurol. 2006;495(1):70-83.

89. Chen Q, Nakajima A, Choi SH, Xiong X, Sisodia SS, Tang YP. Adult neurogenesis is functionally associated with AD-like neurodegeneration. Neurobiol Dis. 2008; 29(2):316-26.

90. Brus M, Keller M, Levy F. Temporal features of adult neurogenesis: differences and similarities across mammalian species. Front Neurosci. 2013;7:135.

91. Sanai N, Berger MS, Garcia-Verdugo JM, Alvarez-Buylla A. Comment on "Human neuroblasts migrate to the olfactory bulb via a lateral ventricular extension". Science. 2007;318(5849):393.

92. Veeraraghavalu K, Choi SH, Zhang X, Sisodia SS. Presenilin 1 mutants impair the self-renewal and differentiation of adult murine subventricular zone-neuronal progenitors via cell-autonomous mechanisms involving notch signaling. J Neurosci. 2010;30(20):6903-15.

93. Demars M, Hu YS, Gadadhar A, Lazarov O. Impaired neurogenesis is an early event in the etiology of familial Alzheimer's disease in transgenic mice. J Neurosci Res. 2010;88(10):2103-17.

94. Blurton-Jones M, Kitazawa M, Martinez-Coria H, Castello NA, Muller FJ, Loring JF, Yamasaki TR, Poon WW, Green KN, LaFerla FM. Neural stem cells improve cognition via BDNF in a transgenic model of Alzheimer disease. Proc Natl Acad Sci U S A. 2009:106(32):13594-9.

95. Ager RR, Davis JL, Agazaryan A, Benavente F, Poon WW, LaFerla FM, Blurton-Jones M. Human neural stem cells improve cognition and promote synaptic growth in two complementary transgenic models of Alzheimer's disease and neuronal loss. Hippocampus. 2015;25(7):813-26.

96. Zhang W, Wang PJ, Sha HY, Ni J, Li MH, Gu GJ. Neural stem cell transplants improve cognitive function without altering amyloid pathology in an APP/ PS1 double transgenic model of Alzheimer's disease. Mol Neurobiol. 2014; 50(2):423-37.

97. Ryu JK, Cho T, Wang YT, McLarnon JG. Neural progenitor cells attenuate inflammatory reactivity and neuronal loss in an animal model of inflamed AD brain. J Neuroinflammation. 2009;6:39.

98. Lee IS, Jung K, Kim IS, Lee H, Kim M, Yun S, Hwang K, Shin JE, Park KI. Human neural stem cells alleviate Alzheimer-like pathology in a mouse model. Mol Neurodegener. 2015;10:38.

99. Kim SU, Lee HJ, Kim YB. Neural stem cell-based treatment for neurodegenerative diseases. Neuropathology. 2013;33(5):491-504.

100. Martinez-Morales PL, Revilla A, Ocana I, Gonzalez C, Sainz P, McGuire D, Liste I. Progress in stem cell therapy for major human neurological disorders. Stem Cell Rev. 2013;9(5):685-99.

101. Tong LM, Fong H, Huang Y. Stem cell therapy for Alzheimer's disease and related disorders: current status and future perspectives. Exp Mol Med. 2015;47:e151.

102. Yu DX, Marchetto MC, Gage FH. Therapeutic translation of iPSCs for treating neurological disease. Cell Stem Cell. 2013;12(6):678-88.

103. Hermann A, Storch A. Induced neural stem cells (iNSCs) in neurodegenerative diseases. J Neural Transm (Vienna). 2013;120 Suppl 1:S19-25. 
104. Hargus G, Ehrlich M, Arauzo-Bravo MJ, Hemmer K, Hallmann AL, Reinhardt $P$, Kim KP, Adachi K, Santourlidis S, Ghanjati F, Fauser M, Ossig C, Storch A, Kim JB, Schwamborn JC, Sterneckert J, Schöler HR, Kuhlmann T, Zaehres H. Origin-dependent neural cell identities in differentiated human iPSCs in vitro and after transplantation into the mouse brain. Cell Rep. 2014;8(6): 1697-703.

105. Hicks AU, Lappalainen RS, Narkilahti S, Suuronen R, Corbett D, Sivenius J, Hovatta O, Jolkkonen J. Transplantation of human embryonic stem cellderived neural precursor cells and enriched environment after cortical stroke in rats: cell survival and functional recovery. Eur J Neurosci. 2009; 29(3):562-74.

106. Tsuji O, Miura K, Okada Y, Fujiyoshi K, Mukaino M, Nagoshi N, Kitamura K, Kumagai G, Nishino M, Tomisato S, Higashi H, Nagai T, Katoh H, Kohda K, Matsuzaki Y, Yuzaki M, Ikeda E, Toyama Y, Nakamura M, Yamanaka S, Okano H. Therapeutic potential of appropriately evaluated safe-induced pluripotent stem cells for spinal cord injury. Proc Natl Acad Sci U S A. 2010;107(28):12704-9.

107. Wernig M, Zhao JP, Pruszak J, Hedlund E, Fu D, Soldner F, Broccoli V, Constantine-Paton $\mathrm{M}$, Isacson $\mathrm{O}$, Jaenisch R. Neurons derived from reprogrammed fibroblasts functionally integrate into the fetal brain and improve symptoms of rats with Parkinson's disease. Proc Natl Acad Sci U S A. 2008;105(15):5856-61.

108. Kang X, Xu H, Teng S, Zhang X, Deng Z, Zhou L, Zuo P, Liu B, Liu B, Wu Q, Wang L, Hu M, Dou H, Liu W, Zhu F, Li Q, Guo S, Gu J, Lei Q, Lü J, Mu Y, Jin M, Wang S, Jiang W, Liu K, Wang C, Li W, Zhang K, Zhou Z. Dopamine release from transplanted neural stem cells in Parkinsonian rat striatum in vivo. Proc Natl Acad Sci U S A. 2014;111(44):15804-9.

109. Han F, Wang W, Chen B, Chen C, Li S, Lu X, Duan J, Zhang Y, Zhang YA, Guo W, Li G. Human induced pluripotent stem cell-derived neurons improve motor asymmetry in a 6-hydroxydopamine-induced rat model of Parkinson's disease. Cytotherapy. 2015;17(5):665-79.

110. Fujiwara N, Shimizu J, Takai K, Arimitsu N, Saito A, Kono T, Umehara T, Ueda Y, Wakisaka S, Suzuki T, Suzuki N. Restoration of spatial memory dysfunction of human APP transgenic mice by transplantation of neuronal precursors derived from human iPS cells. Neurosci Lett. 2013;557 Pt B:129-34.

111. Tong LM, Djukic B, Arnold C, Gillespie AK, Yoon SY, Wang MM, Zhang O, Knoferle J, Rubenstein JL, Alvarez-Buylla A, Huang Y. Inhibitory interneuron progenitor transplantation restores normal learning and memory in ApoE4 knock-in mice without or with Abeta accumulation. J Neurosci. 2014;34(29): 9506-15.

112. Nicholas CR, Chen J, Tang Y, Southwell DG, Chalmers N, Vogt D, Arnold CM, Chen YJ, Stanley EG, Elefanty AG, Sasai Y, Alvarez-Buylla A, Rubenstein JL, Kriegstein AR. Functional maturation of hPSC-derived forebrain interneurons requires an extended timeline and mimics human neural development. Cell Stem Cell. 2013;12(5):573-86.

113. Abdullah Al, Pollock A, Sun T. The path from skin to brain: generation of functional neurons from fibroblasts. Mol Neurobiol. 2012;45(3):586-95.

114. Nakamura M, Okano H. Cell transplantation therapies for spinal cord injury focusing on induced pluripotent stem cells. Cell Res. 2013;23(1):70-80.

115. Wang Y, Yang D, Song L, Li T, Yang J, Zhang X, Le W. Mifepristone-inducible caspase-1 expression in mouse embryonic stem cells eliminates tumor formation but spares differentiated cells in vitro and in vivo. Stem Cells. 2012; 30(2):169-79.

116. Cui L, Guan Y, Qu Z, Zhang J, Liao B, Ma B, Qian J, Li D, Li W, Xu GT, Jin Y. WNT signaling determines tumorigenicity and function of ESC-derived retinal progenitors. J Clin Invest. 2013;123(4):1647-61.

117. Nori S, Okada Y, Nishimura S, Sasaki T, Itakura G, Kobayashi Y, Renault-Mihara F, Shimizu A, Koya I, Yoshida R, et al. Long-term safety issues of iPSC-based cell therapy in a spinal cord injury model: oncogenic transformation with epithelial-mesenchymal transition. Stem Cell Reports. 2015;4(3):360-73.

\section{Submit your next manuscript to BioMed Central and we will help you at every step:}

- We accept pre-submission inquiries

- Our selector tool helps you to find the most relevant journal

- We provide round the clock customer support

- Convenient online submission

- Thorough peer review

- Inclusion in PubMed and all major indexing services

- Maximum visibility for your research

Submit your manuscript at www.biomedcentral.com/submit
Ciomed Central 